\title{
St. Augustinegrass for Florida Lawns ${ }^{1}$
}

\author{
L. E. Trenholm, J. B. Unruh, and T.W. Shaddox ${ }^{2}$
}

\section{St. Augustinegrass (Stenotaphrum secundatum [Walt.]}

Kuntze) is widely adapted to the warm, humid (subtropical) regions of the world. It is believed to be native to the coastal regions of both the Gulf of Mexico and the Mediterranean. St. Augustinegrass is the most commonly used lawn grass in Florida (Figure 1).

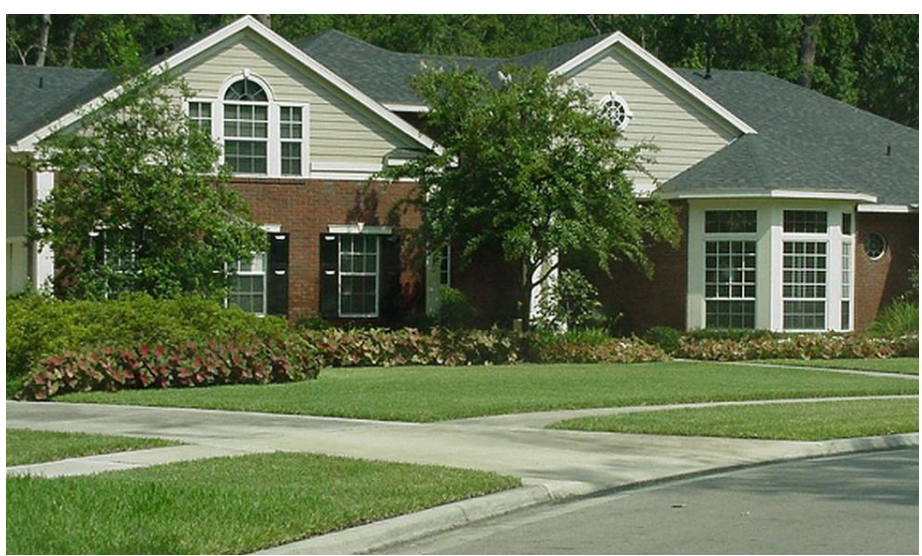

Figure 1. A St. Augustinegrass lawn.

Credits: L. Trenholm, UF/IFAS

\section{Advantages}

St. Augustinegrass produces a green to blue-green dense turf that is well adapted to most soils and climatic regions in Florida. It has relatively good salt tolerance, and certain cultivars have better shade tolerance than other warmseason grass species. St. Augustinegrass establishes quickly and easily and may be planted as sod, sprigs, or plugs.

\section{Disadvantages}

St. Augustinegrass, like most turfgrasses, has certain cultural and pest problems. It requires water to remain green and healthy and may require supplemental irrigation during extended dry periods. It has poor wear tolerance and does not hold up to repeated foot or vehicular traffic. It goes into winter dormancy in parts of the state and turns a brown or tan color until springtime. It produces thatch under high fertilization and irrigation regimes, which may become a health problem for the grass. It has coarse, wide leaves and stems and therefore does not grow as densely as some other species. The major insect pest of St. Augustinegrass is the southern chinch bug (Blissus insularis Barber), which can cause considerable damage if not treated. Some cultivars are also susceptible to diseases, such as gray leaf spot (Pyricularia grisea), large patch (Rhizoctonia solani), and take-all root rot (Gaeumannomyces graminis var. graminis). Chemical weed control can be challenging, particularly when trying to control persistent, grassy weeds, for which there are few herbicide options for use on home lawns.

\section{Cultivars}

There are several cultivars of St. Augustinegrass available for use in Florida. The different cultivars vary in their tolerances to environmental stresses and susceptibility to pests. St. Augustinegrass cultivars can be grouped by their mowing height requirement and leaf texture. Standard cultivars should be mowed at 3.5-4 inches and dwarf cultivars

1. This document is ENH5, one of a series of the Department of Environmental Horticulture, UF/IFAS Extension. Original publication date October 2000. Revised September 2017. Visit the EDIS website at http://edis.ifas.ufl.edu.

2. L. E. Trenholm, professor, turfgrass specialist, Department of Environmental Horticulture; J. B. Unruh, professor, turfgrass specialist, UF/IFAS West Florida Research and Education Center; and T. W. Shaddox, assistant professor, UF/IFAS Fort Lauderdale Research and Extension Center, UF/IFAS Extension, Gainesville, FL 32611.

The Institute of Food and Agricultural Sciences (IFAS) is an Equal Opportunity Institution authorized to provide research, educational information and other services only to individuals and institutions that function with non-discrimination with respect to race, creed, color, religion, age, disability, sex, sexual orientation, marital status, national origin, political opinions or affiliations. For more information on obtaining other UF/IFAS Extension publications, contact your county's UF/IFAS Extension office. 
should be mowed at 2.5 inches. Table 1 lists some relative growth characteristics for currently available cultivars.

\section{Standard Cultivars 'BITTERBLUE'}

'Bitterblue' was selected in the 1930s. Bitterblue has a relatively fine, dense texture and dark blue-green color. It has good cold and shade tolerance and is well adapted for use throughout the state. It should be mowed to a height of $3.5-4$ inches.

\section{'CLASSIC'}

'Classic' is a proprietary cultivar released in the early 2000s by Woerner Turf. It has good cold tolerance and is used throughout Florida and other states. Shade tolerance has not yet been verified by university research, and there is no evidence that it is superior to other cultivars. It should be mowed to a height of 3.5-4 inches. It has a dark green color.

\section{'DELTASHADE'}

'DeltaShade' (Figure 2) is a proprietary release from Environmental Turf in 2005. University research shows that 'DeltaShade' has good shade tolerance, but not as good as the dwarf varieties. It appears to have good cold tolerance, although no university studies have been done to verify this. In some landscapes, it tends to have a lighter green color than some cultivars. It should be mowed to a height of $3.5-4$ inches.

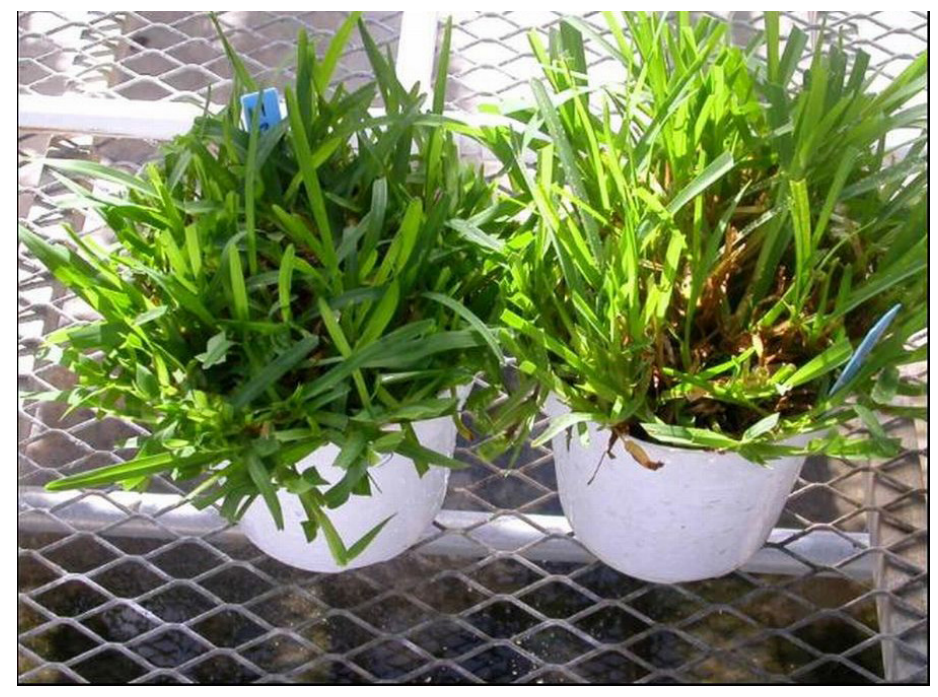

Figure 2. 'Deltashade' (left) and 'Floratam' (right) growing in pots in the greenhouse.

Credits: L. Trenholm, UF/IFAS

\section{'FLORATAM'}

'Floratam' (Figure 3) is an improved St. Augustinegrass that was released jointly in 1973 by the University of Florida and Texas A \& M University. 'Floratam' is the most widely produced and used St. Augustinegrass in Florida. It is a coarse-textured cultivar that has poor cold and shade tolerance relative to other St. Augustinegrass cultivars. It does not persist well in environments that receive less than 6 hours of sunlight daily. It grows vigorously in the spring and summer. When first released, it had UF-documented chinch bug resistance, although that has largely been lost over time and chinch bugs are now a major pest of 'Floratam'. It is also susceptible to gray leaf spot and other diseases. 'Floratam' is not tolerant of herbicides that contain atrazine when applied at temperatures above $85^{\circ} \mathrm{F}$. It should be mowed to a height of 3.5-4 inches.

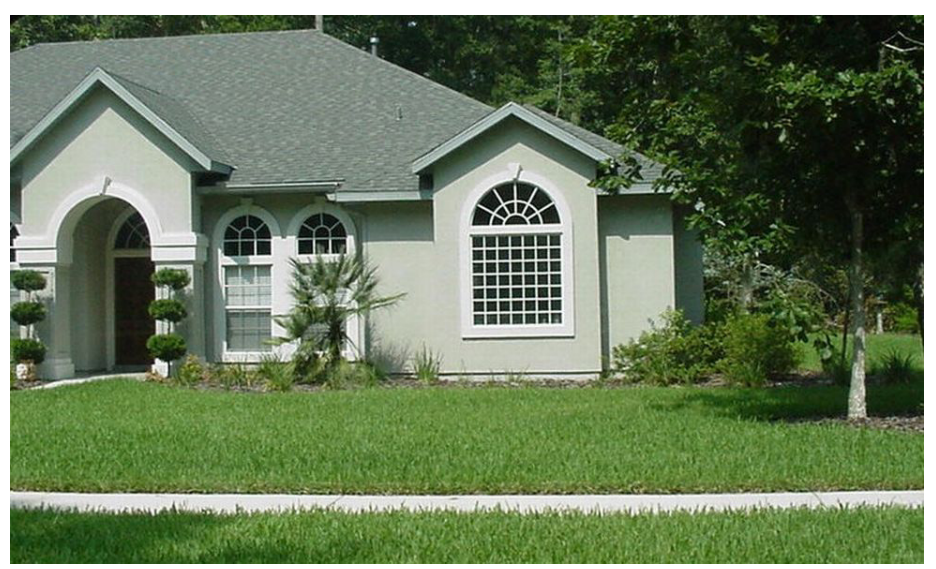

Figure 3. 'Floratam' in the landscape. It is the most commonly used lawn grass in Florida.

Credits: L. Trenholm, UF/IFAS

\section{'PALMETTO'}

'Palmetto' was a selection found by a Florida sod grower in 1988 and released in the mid-1990s. It is sometimes referred to as a "semi-dwarf cultivar" with a shorter growth habit and internodes than many other cultivars, but it is slightly larger than the dwarf St. Augustinegrass cultivars. It does well in full sun or partial shade, but not in dense shade. It is sometimes referred to as drought tolerant, but research has not shown that it has any greater degree of drought tolerance than other St. Augustinegrass cultivars. It is not resistant to insects and sometimes has problems with disease, particularly in Florida's humid environment. It tends to have a lighter green color than many other cultivars. It should be mowed to a height of 3-4 inches.

\section{'RALEIGH'}

'Raleigh' is a cold-hardy cultivar released by North Carolina State University in 1980. It has a medium green color and a coarse texture. It is susceptible to chinch bugs and large patch disease, but is used in northern Florida due to its tolerance to lower temperatures. It is highly susceptible to gray leaf spot. During peak summertime heat, 'Raleigh' has been noted to yellow and grow less aggressively than it does at cooler temperatures. Supplemental iron applications can reduce this yellowing tendency. 'Raleigh' is best adapted to 
the heavier clay soils with medium to low soil $\mathrm{pH}$ of north and northwest Florida.

\section{Dwarf Cultivars 'CAPTIVA'}

'Captiva' (Figure 4) was released by the Florida Agricultural Experiment Station in 2007. It has dark green, short, narrow leaf blades and reduced vertical leaf extension, making it a slower-growing cultivar. It exhibits improved tolerance to chinch bugs compared to other commercially available cultivars. It is somewhat susceptible to diseases such as large patch and take-all root rot, particularly if it receives excess fertilizer or irrigation. Although it has not been officially evaluated for shade tolerance, the dwarf St. Augustinegrass cultivars all have better tolerance to shade than the standard cultivars. It should be mowed to a height of $2-2.5$ inches.

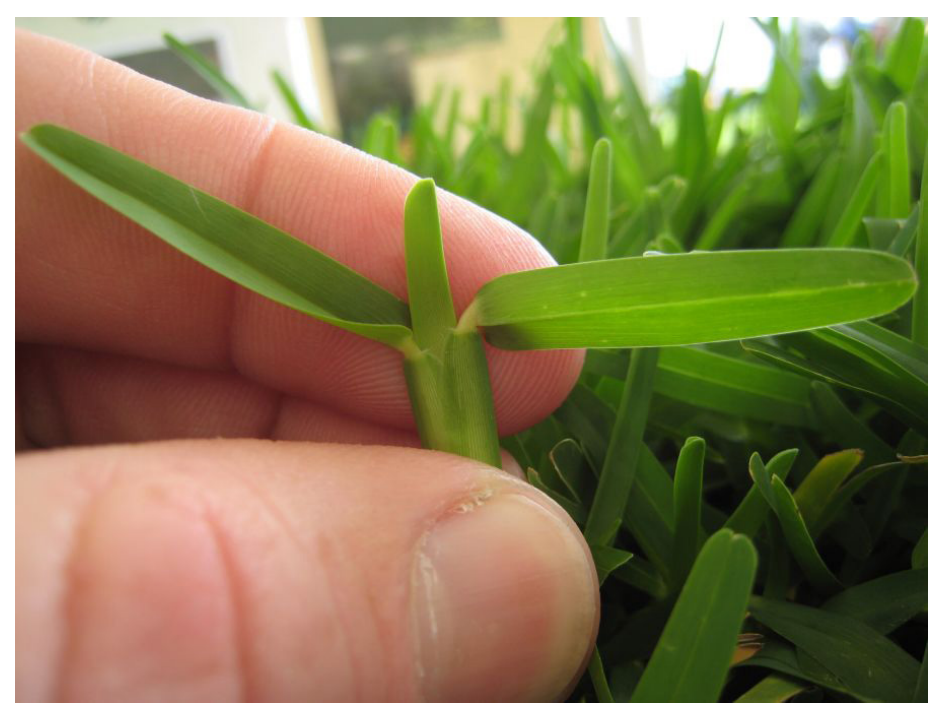

Figure 4. 'Captiva' St. Augustinegrass.

Credits: K. Kenworthy, UF/IFAS

\section{'DELMAR'}

'Delmar' is often sold as sod or plugs. It has good shade tolerance and also does well in full sun. It has short internodes, a dark green color, and good cold tolerance. 'Delmar' is susceptible to chinch bugs, tropical sod webworms (Herpetogramma phaeopteralis), and large patch. Like the other dwarf cultivars, it has a tendency to become thatchy. It should be mowed to a height of 2-2.5 inches.

\section{'SAPPHIRE'}

'Sapphire' has a blue-green leaf color, purple stolon color, and long leaf blades that remain folded, giving the grass a fine leaf appearance. It spreads rapidly and grows aggressively during the growing season. It is susceptible to most major pests associated with St. Augustinegrass. 'Sapphire' should be mowed to a height of 2-2.5 inches.

\section{'SEVILLE'}

'Seville' is a fine-leaved variety with a dark green color and a low growth habit. It is susceptible to chinch bug and webworm damage. Like the other dwarf cultivars, 'Seville' tends to be prone to thatch. 'Seville' performs well in both shade and full sun, but is cold sensitive. It is not as common as Delmar, but is also a good choice for shady sites. 'Seville' should be mowed to a height of 2-2.5 inches.

\section{Establishment of St. Augustinegrass}

Although St. Augustinegrass can be planted year-round in warmer regions of Florida, the best time to plant any warmseason grass is during its time of active growth for quickest establishment. It is also best to avoid temperature extremes if possible, especially if freezing temperatures are forecast. In south Florida, the optimal time for establishment is late fall, winter, or spring. In central and north Florida, try to avoid establishment during cold winter or hot, dry summer months.

St. Augustinegrass is established by vegetative propagation only, which includes sod, plugs, or sprigs. Vegetative propagation means that plant parts with growing points are used for planting rather than seeds. St. Augustinegrass has stolons (aboveground stems) that have areas of actively dividing cells at the nodes. These areas are capable of generating new shoot and root growth and are responsible for lateral growth of St. Augustinegrass along the ground.

It is important to provide irrigation on the correct schedule when grass is newly planted. Multiple, short (5-10 minutes) irrigations throughout the course of the day for 7-10 days following planting helps the grass establish without drying out. For the next 7-10 days, irrigate once a day to apply $1 / 4-1 / 2$ inch of water. After this, frequency should be reduced to 2-3 times weekly, again applying $1 / 4-1 / 2$ inch of water. Three to four weeks after sodding, the grass should be fully established and irrigation can begin on an as-needed basis. For more information, refer to ENH9, Watering Your Florida Lawn (http://edis.ifas.ufl.edu/lh025).

A newly planted lawn should not be fertilized until 30-60 days after planting. Because the root system is not developed on new plantings, fertilizing before this can result in nutrient leaching or runoff and potential pollution of ground or surface waters. Sod is generally fertilized prior to harvest and does not need supplemental nutrients for this time, so the delay in fertilizing will not affect turf health or establishment. The lawn should not be mowed 
until the roots have had a chance to peg down into the soil, generally 14-21 days after planting. Pegging means that the sod cannot be lifted without appreciable force. For more information on preparing the site and establishment, refer to ENH03, Establishing Your Florida Lawn http://edis.ifas. ufl.edu/lh013).

\section{Sodding}

Sodding is the fastest way to establish a lawn because it provides complete ground cover and it is not necessary to wait for it to fill in (Figure 5). Sodding reduces potential weed competition that can occur when using other planting methods that leave bare ground. However, it is important to remember that the grass is still vulnerable at this stage, and it is not yet safe for play or other activities. It is quite dependent until the roots have developed and extended down into the soil. Sod pieces should be laid over bare, moist soil in a staggered brick-like pattern, and the edges should be fitted tightly together to avoid any open cracks. Rolling and watering thoroughly ensures good contact with the soil for fast rooting. For more information on preparing the ground and planting, please refer to ENH02, Preparing to Plant a Florida Lawn (http://edis.ifas.ufl.edu/lh012).

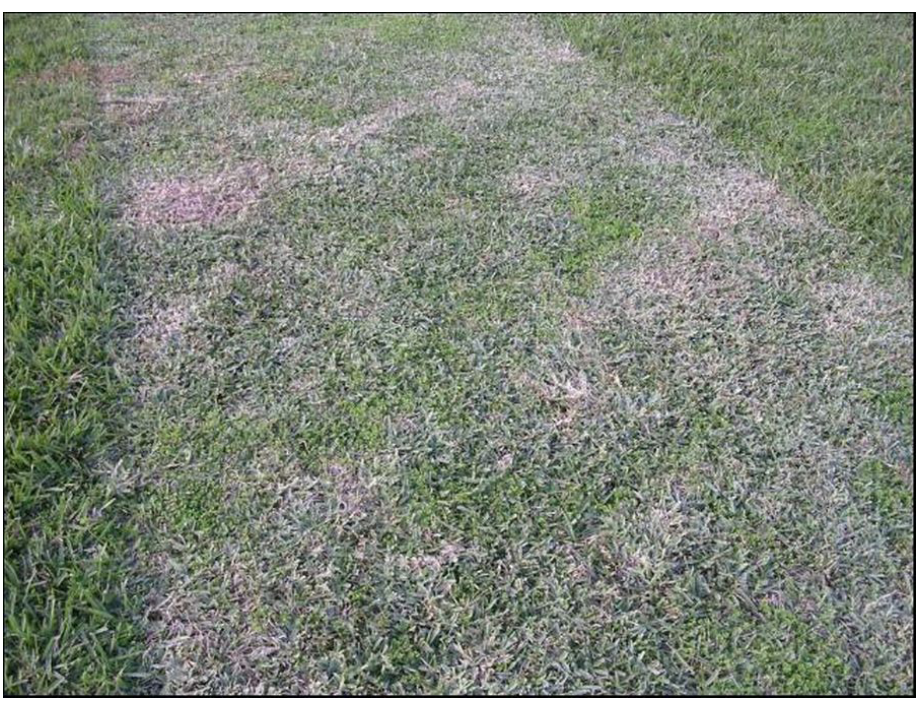

Figure 5. "Scalping," or mowing grass too short, can injure the lawn. Always mow at the highest recommended height for the cultivar and species.

Credits: L. Trenholm, UF/IFAS

\section{Sprigging}

Sprigging is less expensive than sodding, but it takes longer for the lawn to establish. Sprigs contain nodes on stolons, which are planted end-to-end in furrows 6-12 inches apart. Stolons should be covered with soil, but leaf blades should be exposed. The soil should be tamped and thoroughly saturated. Soil needs to be kept moist until shoots and roots begin to grow.

\section{Plugging}

A number of St. Augustinegrass cultivars are available commercially in garden centers as plugs. Sod also can be made into plugs by cutting it into small squares. Spacing of plugs varies from 6 to 24 inches. The closer spacing provides coverage more quickly and reduces weed intrusion. Plugs are placed in holes of the same size or in open furrows and tamped into place. A thorough watering completes the installation. The turf should then be cared for like a sprigged lawn.

\section{Maintenance}

Proper lawn maintenance practices are the best means for avoiding pest or stress problems and for maintaining a healthy lawn. St. Augustinegrass requires inputs of fertilizer to maintain good cover and healthy growth characteristics. During certain times of the year, it generally requires supplemental irrigation. Pesticides may be needed periodically, but their use can be minimized if other cultural practices (mowing, irrigation, fertilization) are done correctly and if Integrated Pest Management (IPM) practices are followed.

\section{Fertilization}

Proper fertilization is very important for sustaining a healthy lawn. Fertilization and other cultural practices influence the overall health and quality of the lawn and reduce its vulnerability to numerous stresses, including weeds, insects, and disease. It is very important that anyone fertilizing their lawn be familiar with and follow the Florida-Friendly Landscaping ${ }^{\text {Tw }}$ Best Management Practices (FFL BMPs). These practices are designed to maintain healthy lawns and reduce any potential nonpoint source pollution of water resources that might result from lawn and landscape fertilization and other cultural practices. There are now state and, in some cities and counties, local regulations that cover lawn fertilization. Be sure to be aware of these regulations and always follow the directions on the fertilizer bag. For more information on BMPs, please refer to ENH979, Homeowner Best Management Practices for the Home Lawn (http://edis.ifas.ufl.edu/ep236).

A soil test should be done prior to planting or if purchasing a home with an existing lawn to determine the soil $\mathrm{pH}$ and salinity. The local UF/IFAS Extension office has instructions and supplies for taking soil samples and submitting them to the UF/IFAS Extension Soil Testing Laboratory for analysis. Refer to http://soilslab.ifas.ufl.edu/ESTL\%20Home.asp for more information on obtaining and submitting a soil sample. 
A recent revision of the Florida Urban Turfgrass Fertilization Rule allows for application of up to $2 \mathrm{lbs}$ of $\mathrm{N}$ per 1,000 square feet when applying fertilizer in the spring or summer and if using a fertilizer that has at least $65 \%$ controlled release nitrogen. No more than $0.7 \mathrm{lbs}$ of soluble (quick release) $\mathrm{N}$ per 1,000 square feet can be applied at any one time (http://edis.ifas.ufl.edu/ep353). For information on determining how much fertilizer this equals, please refer to ENH962, Figuring out Fertilizer for the Home Lawn (http:// edis.ifas.ufl.edu/ep221).

As a general rule, the first fertilizer application of the year should be early April in central Florida and mid-April in north Florida. In south Florida, fertilizer applications may be made throughout the year since growth is year-round. University of Florida guidelines for lawn grass fertilization offer a range of fertilizer rates over which a particular species may be successfully maintained in the various regions of the state. These ranges account the effect that localized microclimates can have on turfgrass growth. A range of rates allows for these environmental variations. An example of this would be a typical home lawn that is partially shaded and partially sunny. The grass growing in the shade needs less fertilizer than that growing in full sun. Fertilization is also affected by soil type, organic matter in soils, and practices such as clipping management. Additionally, a newly sodded lawn on a sand soil with little organic matter requires more fertilizer than a lawn that has been fertilized for years. In Florida, new homes and new developments may be next to much older developed landscapes, and a one-size-fits-all approach to fertilization is not reasonable. These guidelines provide a base range from which the end user can begin a fertilization program. The homeowner is encouraged to initiate a program based on these guidelines and to adjust it over time based on how the turfgrass responds.

The fertilizer guidelines divide the state into three geographical locations as indicated in Table 2. All rates are in pounds of nitrogen per 1000 square feet per year. For how to apply the correct amounts, refer to ENH962, Figuring out Fertilizer for the Home Lawn (http://edis.ifas.ufl.edu/ep221).

Depending on geographical location, fertilizer should be applied to St. Augustinegrass in 2-6 applications from spring green-up through fall (or year-round in south Florida). Do not apply too early in the growing season, particularly in north Florida, because late-season frosts may damage the grass and the root system will not be fully grown in at this time to assimilate the nutrients. Likewise, do not fertilize too late in the year after growth has subsided.
On high-pH (> 7.0) soils or where high-pH water is applied, yellow leaf blades may be an indication of iron or manganese deficiency. Application of soluble or chelated sources of these micronutrients can provide a green-up in these cases.

Note that iron is not a substitute for nitrogen, which provides the building blocks for turfgrass growth and is required for turf health. While both iron and nitrogen deficiencies result in turfgrass yellowing, they are distinctly different deficiencies in plants. Applying iron does not cure yellowing due to nitrogen deficiency and iron fertilizer is not a substitute for nitrogen fertilizer. Foliar iron fertilizers, such as iron sulfate or chelated iron solutions, help alleviate iron deficiencies and nitrogen fertilizers applied according to UF/IFAS guidelines alleviate nitrogen deficiencies.

\section{Mowing}

Proper mowing practices are necessary to keep any lawn healthy and attractive. Standard St. Augustinegrass cultivars ('BitterBlue,' 'Classic', 'Floratam', etc.) should be maintained at a height of 3.5-4 inches. Repeatedly mowing at lower heights increases the stress on the lawn, discourages deep rooting, increases the chance for scalping if a mowing event is missed or postponed due to weather, and may increase susceptibility to pest problems (Figure 6). Maintaining the right height helps the grass develop a deep root system and gives a better appearance to the turf. No more than $1 / 3$ of the leaf blades should be removed with any mowing. If possible, mowing height should be increased during periods of moisture stress or if the grass is growing in shade. Dwarf varieties have a lower growth habit and should be mowed at 2-2.5 inches for optimum health. Mowing too infrequently or too high and over-watering and over-fertilizing can cause a thatch buildup.

A rotary mower can be used on St. Augustinegrass. It is important to keep the blades sharp and well adjusted for a clean cut. Dull blades give the lawn a brownish cast because a ragged cut shreds the leaf blades rather than cuts them. During the growing season, blades should be sharpened monthly. St. Augustinegrass typically requires weekly mowing during the growing season and less frequent mowing during the cooler months of the year. In north Florida, mowing may not be required during winter months.

Grass clippings should be left on a lawn that is mowed at the proper height and frequency. Under these conditions, clippings do not contribute to the thatch layer. Clippings put nutrients and organic matter back into the soil system. If clippings are excessive (e.g., clumping occurs), let them 
dry out and then disperse them over the lawn. For more information on mowing, please refer to ENH10, Mowing Your Florida Lawn (http://edis.ifas.ufl.edu/lh028).

\section{Watering}

Irrigating on an "as-needed" basis is the best way to maintain any established, mature grass, as long as the proper amount of water is applied when needed. Irrigation is needed when leaf blades begin to fold up, wilt, or turn a blue-gray color, or when footprints remain visible after walking on the grass (Figure 6). Apply $1 / 2-3 / 4$ inch of water per application. This applies water to roughly the top 8 inches of soil where the majority of the roots are. Be sure to follow any local watering restrictions.

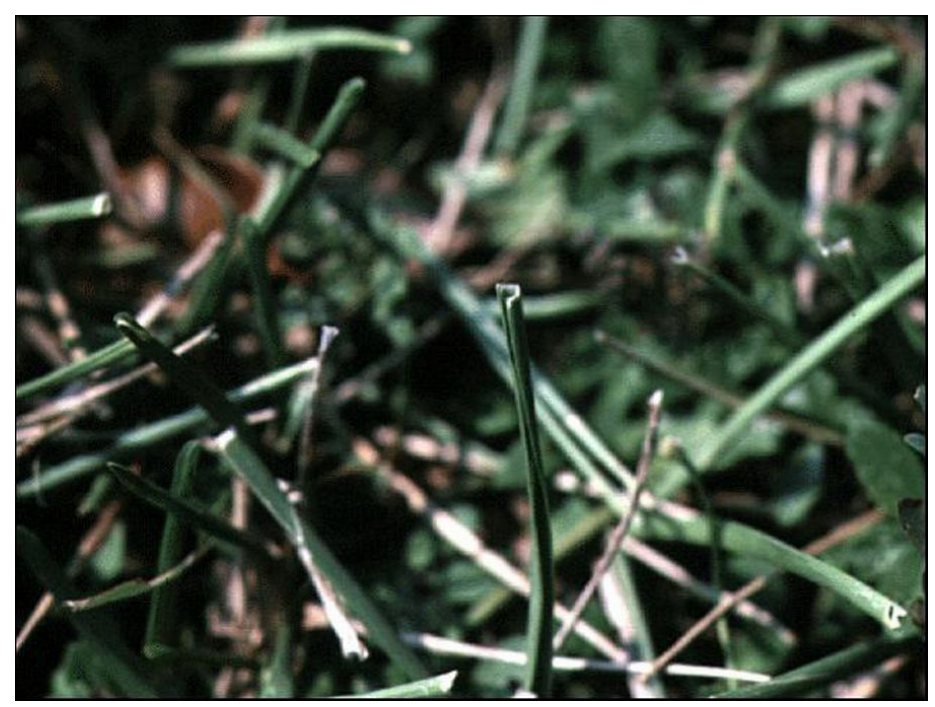

Figure 6. Let your lawn tell you when to water. Look for folded leaf blades, as seen here.

Credits: L. Trenholm, UF/IFAS

To determine the amount of irrigation supplied by a sprinkler system, place several straight-sided cans (e.g., tuna fish or cat food) throughout each irrigation zone and run each zone to determine how long it takes to fill the cans to the $1 / 2$ - or $3 / 4$-inch level, then record the time. Each zone will likely take different amounts of time to give the same quantity of water. The recorded run times for each zone should then be programmed into the irrigation clock for automated systems. If the variation in the catch cans is great, a more thorough audit of the irrigation system is needed. Refer to ENH61, How to Calibrate Your Sprinkler System (http://edis.ifas.ufl.edu/lh026).

The frequency of irrigating should change seasonally, with less water needed in the fall and winter. The amount applied should not be adjusted-only the frequency. For further information about recommended watering practices, refer to ENH9, Watering Your Florida Lawn (http://edis.ifas.ufl. edu/lh025) and ENH63, Let Your Lawn Tell You When to Water (http://edis.ifas.ufl.edu/ep054).

Proper watering practices help maintain a healthy lawn that has fewer stress and insect problems. If large patch or gray leaf spot diseases are a continuous problem, excessive watering and nitrogen fertilization may be responsible. Certain weeds, such as dollarweed and sedges, also thrive in soils that are continuously wet.

\section{Pest Management Weeds}

The best approach to weed control is a healthy, vigorous lawn. Weed problems in a lawn indicate that the turf has been weakened by improper management practices or damage from pests. Proper management practices can eliminate many weed problems. If weeds are a persistent problem, herbicides labeled specifically for St. Augustinegrass should be used. If an herbicide is needed, preemergence herbicides (i.e., pendimethalin, benefin, bensulide, atrazine, or others) can be applied to control crabgrass if it was present in previous years. Timing is critical for successful control. As a general rule, preemergence herbicides for crabgrass should be applied February 1 in south Florida, February 15 in central Florida, and March 1 in north Florida. Note: Preemergence herbicides will not control weeds that are actively growing.

Postemergence herbicides (e.g., atrazine) should be applied as needed for control of summer annual and perennial broadleaf or grassy weeds. These materials should not be applied if the turf is under moisture stress or when air temperatures exceed $85^{\circ} \mathrm{F}$. Your local UF/IFAS Extension office can assist with weed identification and provide the latest recommendations.

Many commercial "weed-n-feed" formulations provide control, but they should be used with caution because certain plant materials may not be tolerant. These herbicides can damage landscape plants whose roots may extend far under the lawn. These materials should only be used when a lawn has a uniform weed population. If weeds exist only on a portion of the lawn, "weed-n-feed" products should not be applied to the entire lawn. If the situation warrants the use of a "weed-n-feed" product, it is important to determine if the manufacturer's recommended rate of application supplies the amount of fertilizer needed by the turfgrass and the amount of herbicide that is required for weed control. Supplemental applications of fertilizer or herbicide may be required if the fertilizer/herbicide product does not supply enough fertilizer to meet the fertility needs 
of the turfgrass or the amount of herbicide needed for weed control. Carefully read the label before use and follow all label directions. Refer to ENH884, Weed Management in Home Lawns http://edis.ifas.ufl.edu/ep141), for more information.

\section{Insects}

The major insect pest of St. Augustinegrass is the southern chinch bug (Figure 7). Chinch bugs are foliar-feeding insects that suck plant juices through a needlelike beak, causing yellowish to brownish patches in turf (Figure 8). Injured areas are usually first noticed as the weather begins to warm in areas along sidewalks, adjacent to buildings, and in other water-stressed areas where the grass is in full sun.

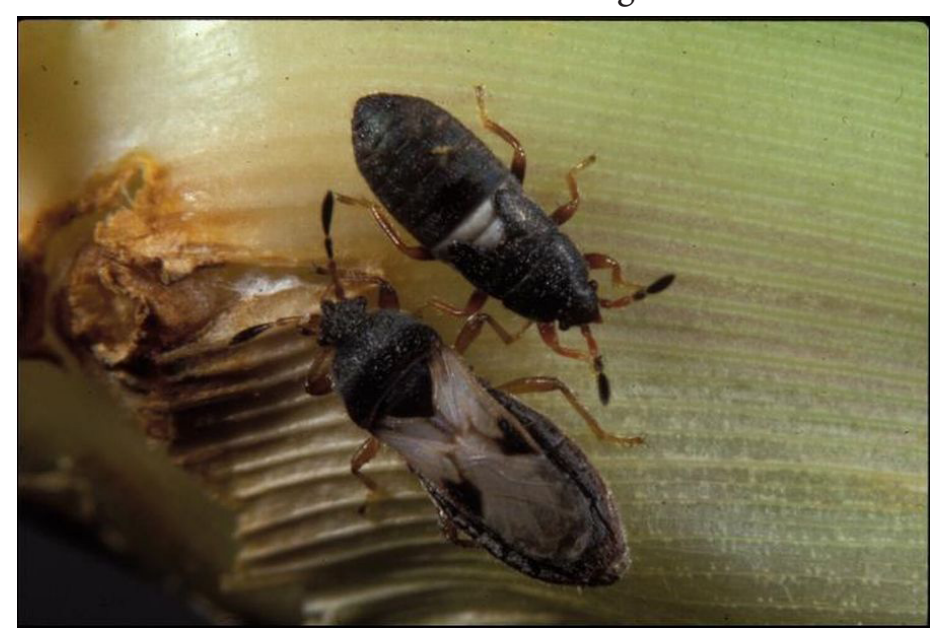

Figure 7. Adult chinch bugs.

Credits: L. Buss, UF/IFAS

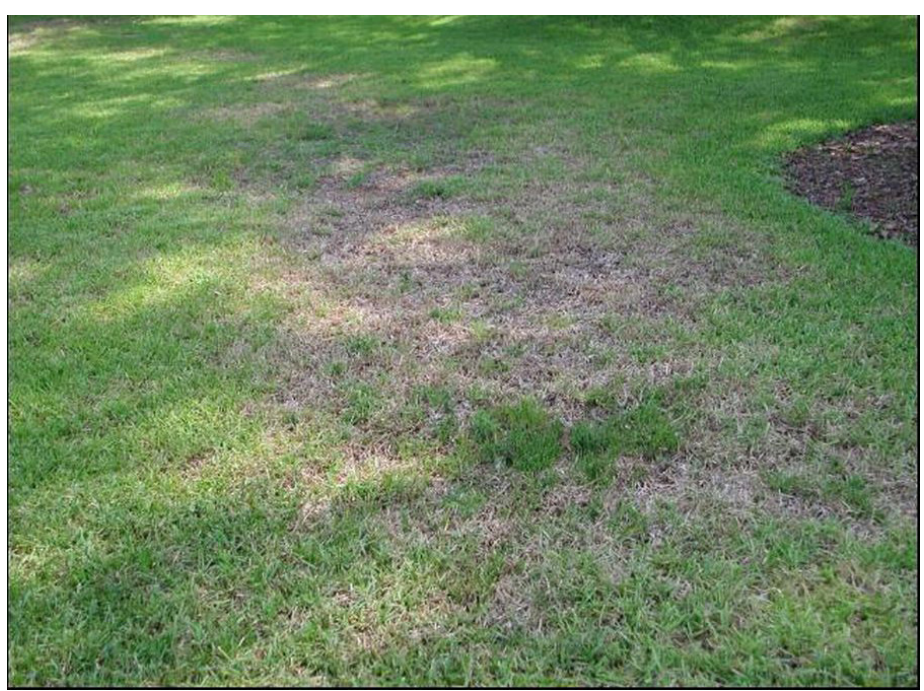

Figure 8. Chinch bug damage.

Credits: E. Buss, UF/IFAS

Check for chinch bugs by removing the ends of a coffee can, inserting one end into the soil at the margin of suspected damaged areas, and filling it with water. Chinch bugs will float to the water surface within 5 minutes. In areas where chinch bugs are a serious problem, a single, thorough insecticide treatment may offer only temporary control. Therefore, repeat applications may be required. Some populations of this insect have become resistant to synthetic pyrethroid insecticides.

Other insect pests, including webworms, armyworms, grass loopers, and mole crickets can damage St. Augustinegrass. Mole crickets damage turfgrass areas primarily by creating tunnels or soft mounds while searching for food. Additional damage may result from small animals digging through the soil profile in search of the mole crickets as food. Check for mole crickets by examining an area for tunnels or by applying 2 gallons of water mixed with $1 \frac{1 / 2}{2}$ ounces of liquid detergent soap per 2 square feet in suspected damaged areas. Mole crickets will surface in several minutes.

White grubs are another pest of St. Augustinegrass. These can be found by lifting the grass to a depth of about 2 inches. Grubs can be seen feeding on the roots at this level. For more information on insect control, refer to ENY300, Insect Pest Management on Turfgrass (http://edis.ifas.ufl. edu/ig001).

\section{Diseases}

Large patch (Figure 9) and gray leaf spot (Figure 10) are two major disease problems of St. Augustinegrass. Large patch occurs in warm, humid weather and is encouraged by excessive nitrogen. It is generally most noticeable during the spring and fall months. Gray leaf spot occurs during the summer rainy season and is primarily a problem on new growth. Both diseases can be controlled with fungicides.

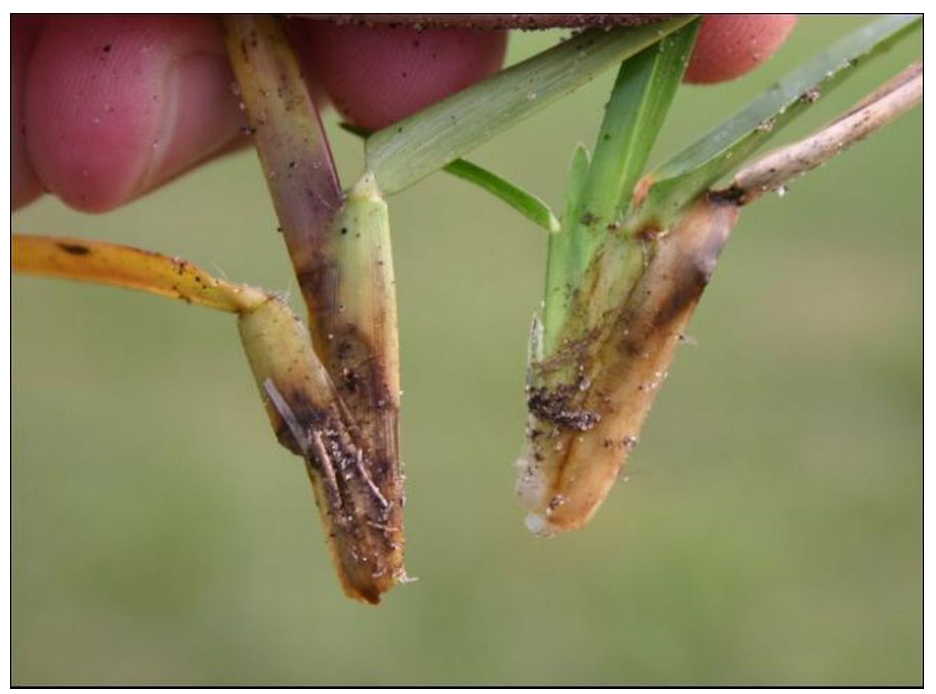

Figure 9. Large patch symptoms on St. Augustinegrass. Credits: P. Harmon, UF/IFAS 


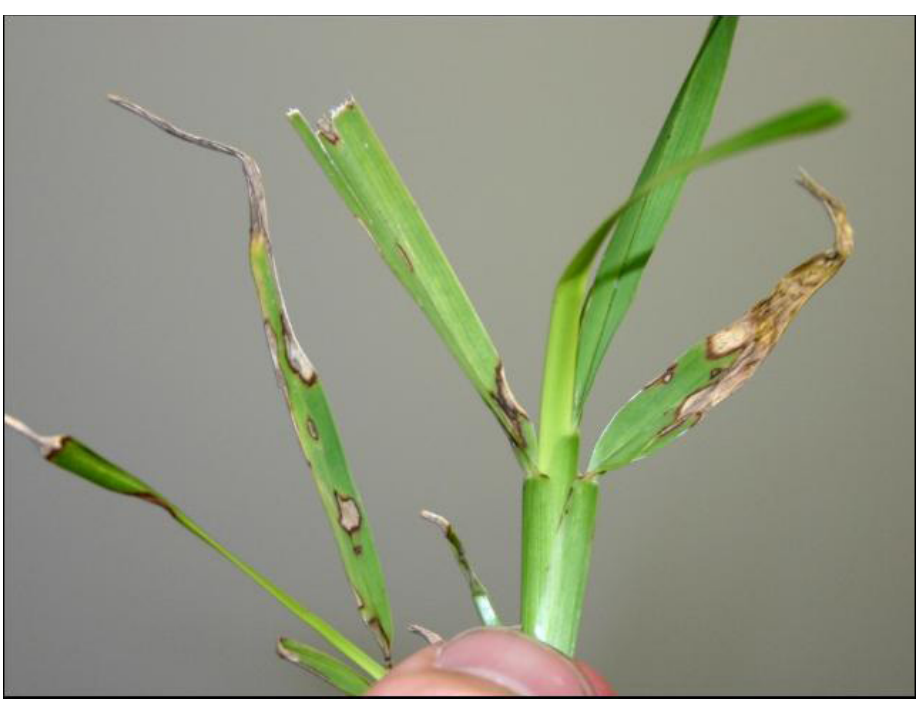

Figure 10. Gray leaf spot symptoms on St. Augustinegrass. Credits: P. Harmon, UF/IFAS

Other St. Augustinegrass disease problems originate in the root system. Take-all root rot (Gaeumannomyces graminis var. graminis) occurs under high moisture or stress conditions. When symptoms are noticeable aboveground, the disease is usually in an advanced stage. Following proper cultural practices is the best defense against this disease. Refer to SS-PLP-14, Turfgrass Disease Management (http:// edis.ifas.ufl.edu/lh040), for more information.

\section{Nematodes}

Several types of nematodes infest St. Augustinegrass lawns. Population peaks of nematodes typically occur in late April to early May and again in late August to early September. Damage symptoms (Figure 11) include thin stand density, less vigorous growth, a weakened root system, slow recovery following rain or irrigation application, and certain weeds such as prostrate spurge and Florida pusley. Plant parasitic nematode levels can only be positively identified through laboratory procedures. The local county Extension office can provide information on submitting soil samples to the University of Florida Nematode Assay Laboratory. There are currently no effective nematode controls for use in the home lawn. Cultural controls include encouraging deep turfgrass rooting by raising the mowing height, irrigating less frequently but more deeply, and providing ample soil potassium. For more information on nematodes, refer to ENY006, Nematode Management in Residential Lawns (http://edis.ifas.ufl.edu/ng039).

\section{Other Problems}

Other factors can also decrease the quality of a lawn.

Excessive shade, compacted soils, over- or underwatering, improper mowing, traffic, and high or low $\mathrm{pH}$ can all cause a lawn to perform poorly. It is important to recognize what the source of the problem is and to correct it if possible. For more information on these types of stresses, refer to ENH153, Environmental Stresses and Your Florida Lawn (http://edis.ifas.ufl.edu/ep070).

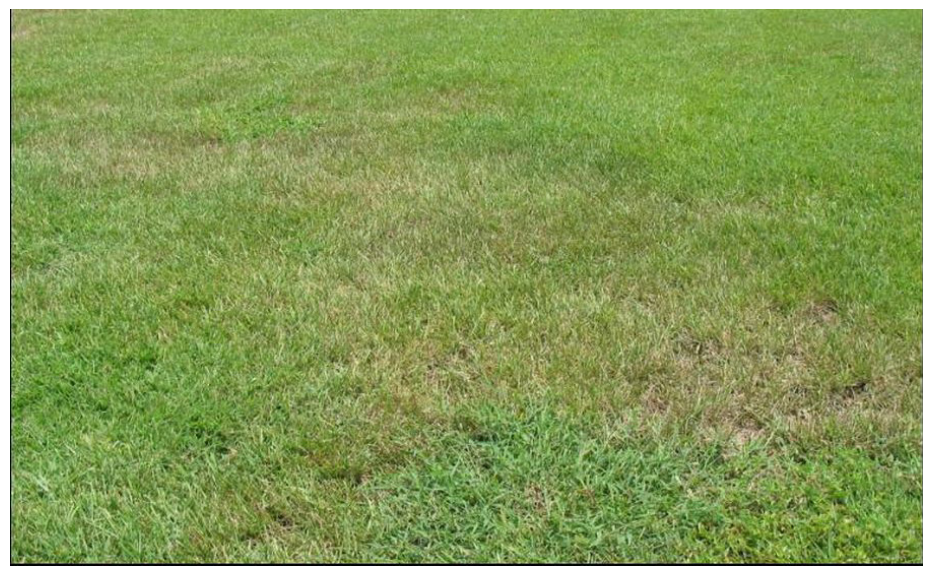

Figure 11. Signs of nematode damage in St. Augustinegrass. Credits: W. Crow, UF/IFAS

\section{Thatch Removal}

Thatch is the layer of undecomposed, stolons, roots, and crowns intermingled with soil (Figure 12). Leaving clippings on the lawn does not cause thatch because clippings are readily broken down by microbes in the soil. Thatch development is greatest in grass that is overfertilized or overwatered. An excessive thatch layer reduces water penetration and can bind up fertilizer or pesticides. In severe cases, roots may be seen actually growing aboveground and rooting into the thatch layer. This is a very unhealthy condition and leaves the lawn vulnerable to many stresses.

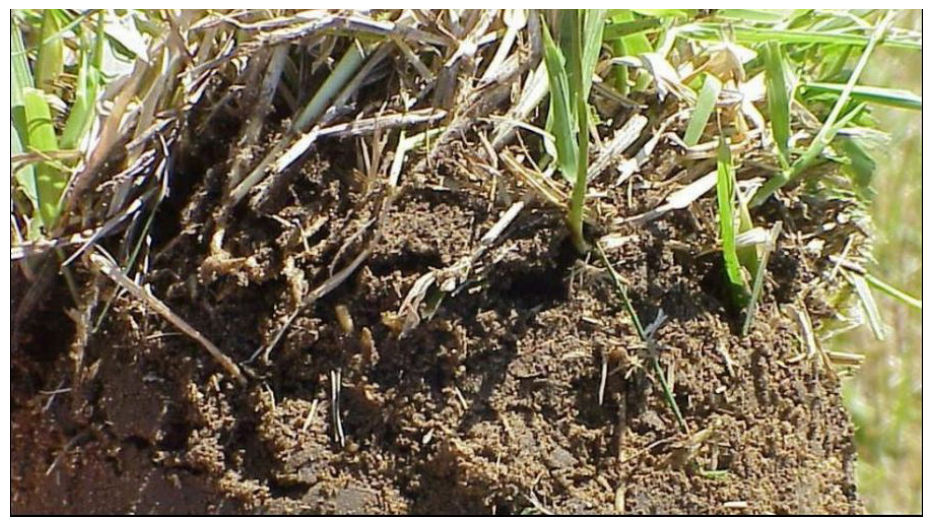

Figure 12. Thatch layers can develop in St. Augustinegrass, especially when fertilization or irrigation rates are high.

Credits: J. B. Unruh, UF/IFAS

If the thatch layer exceeds 1 inch, it may be removed by vertical mowing, or "verticutting," in early spring to midsummer. Verticutting uses vertical blades that slice through the thatch and slightly into the soil, resulting in much of the dead material being removed from the top of the lawn. A 3 -inch spacing between the dethatching blades is best for St. Augustinegrass. Caution: Vertical mowing may result in 
damaged turf that requires a period of recuperation. Do not attempt vertical mowing unless the grass is actively growing. Verticut should be done in an east to west or north to south pattern, but not in all four directions. Debris should be removed by raking, sweeping, or vacuuming, followed by a conventional mowing to improve turf appearance and immediate irrigation to prevent root zone dehydration.

One week after vertical mowing, fertilizer should be applied at the rate of $1 / 2$ pound of nitrogen per 1000 square feet to encourage recovery. This material must be watered into the soil immediately following application to prevent plant burn. Periodic topdressing (adding a uniform layer of soil on top of the grass) with $1 / 4$ inch of soil similar to that underlying the turf is the best method to alleviate thatch accumulation; however, the physical labor required limits the practicality of this method for most homeowners. If topdressing, be sure to use soil that is free of weed seeds and nematodes and be careful not to exceed recommended topdressing rates.

\section{Renovation}

Large, bare areas can be replanted by broadcasting sprigs (1 bushel per 1000 square feet), by planting 2 -inch plugs every 12 inches, or by sodding. These areas should be kept continuously moist with light, frequent irrigations several times daily until runners develop or sod is well rooted. Over time, irrigation frequency should be gradually reduced, but duration should be increased to apply $1 / 2-3 / 4$ inch of water. Refer to ENH03, Establishing Your Florida Lawn (http://edis.ifas.ufl.edu/lh013), for more information. 
Table 1. Relative growth characteristics for St. Augustinegrass cultivars.

\begin{tabular}{|l|c|c|c|c|c|c|}
\hline \multicolumn{1}{|c|}{ Cultivars } & $\begin{array}{c}\text { Mowing height } \\
\text { (inches) }\end{array}$ & Cold tolerance & Shade tolerance & $\begin{array}{c}\text { Chinch bug } \\
\text { resistance }\end{array}$ & Green color \\
\hline 'Bitterblue' & $3.5-4$ & Good & Good & Slight & Dark \\
\hline 'Classic' & $3.5-4$ & Good & Medium & Unknown & Dark \\
\hline 'DeltaShade' & $3.5-4$ & Good & Good & Unknown & Good \\
\hline 'Floratam' & $3.5-4$ & Poor & Fair & Slight & Dark \\
\hline 'Floralawn' & $3.5-4$ & Poor & Fair & Slight & Dark \\
\hline 'Palmetto' & $3-4$ & Fair & Fair & Unknown & Loarse \\
\hline 'Raleigh' & $3-4$ & Very good & Medium & Poor & Frearse \\
\hline 'Sapphire' & $2-2.5$ & Unknown & Unknown & Unknown & Medium \\
\hline 'Captiva' & $2-2.5$ & Good & Good & Good & Medium \\
\hline 'Delmar' & $2-2.5$ & Good & Good & Poor & Dark \\
\hline 'Seville' & $2-2.5$ & Fair & Good & Slight & Dark \\
\hline
\end{tabular}

Table 2. Annual fertilization recommendations for St. Augustinegrass in three regions of Florida.

\begin{tabular}{|c|c|}
\hline Location $^{1}$ & $\begin{array}{c}\text { N fertility guideline } \\
\text { (lbs N/1000 sq ft/year) }\end{array}$ \\
\hline North Florida & $2-4$ \\
\hline Central Florida & $2-5$ \\
\hline South Florida & $4-6$ \\
\hline
\end{tabular}

${ }^{1}$ North Florida in this example is considered to be anything north of Ocala. Central Florida is defined as anything south of Ocala to a line extending from Vero Beach to Tampa. South Florida includes the remaining southern portion of the state. 